Avaliable online at

https://www.syekhnurjati.ac.id/jurnal/index.php/tamaddun/index

Published by Departement of History and Islamic Culture, Faculty of Ushuluddin Adab and Dakwah IAIN Syekh Nurjati Cirebon, Indonesia

\title{
Preanger Stelsel; \\ Kisah Tentang Bisnis Kopi Belanda di Tanah \\ Cirebon-Priangan
}

\author{
Dr. A. Syatori, M.Si \\ Fakultas Syari'ah dan Ekonomi Islam \\ IAIN Syekh Nurjati Cirebon
}

\begin{abstract}
This paper provides an overview of the history of the VOC (Verenigde Oost Indische Compagnie) policy called the Preanger Stelsel. This policy was initiated by the VOC in 1707 in the Cirebon-Priangan region. This policy, which was often referred to as the forced coffee cultivation system, was implemented by the VOC as a sign of the strengthening of the VOC's economic domination over the Cirebon Sultanate, which began in 1681.

In carrying out its policy, as the basis for its operations, the VOC implemented an economic system which it had implemented which was called the Verplichte Leverantien, namely mandatory submission at a price that was favorable to the Company. In addition, the VOC as the political ruler in charge of the subdued regents, no different from the king, felt entitled to collect part of the produce and labor from the conquered people as a periodic offering. This obligatory offering which is an annual periodic fee is called a Contingent. Unlike Verplichte Leverantien, in this Contingenten there is an element of underlying sovereign rights. Although in fact nature and legal basis are very different between Verplichte Leverantien (which is more civil law in nature) and Contingenten (which is public law), in its implementation the two mandatory submissions are difficult to distinguish, because Verplichte Leverantien sometimes runs without payment, while Contingent can occur with a reward as collection fees or collection fees.
\end{abstract}

Through this policy of forced coffee cultivation, the VOC obtained tremendous profits from the Cirebon-Priangan area until the end of the 18th century. Under the influence of this system, people are deprived of their freedom to find their source of life. The VOC as the ruler took land ownership rights and claimed rights over them, by demanding peasants through the 
Bupatis as intermediaries. However, the farmers did not remain silent in facing this policy. In their way of doing insubordination. Among them they refuse to deposit the harvest or only part of it is their obligation. They do this by throwing the crop away or burying it to keep it from being taken to the warehouse. They avoided their obligations. There were also those who left it to middlemen who gave higher prices than the VOC.

Keywords: Preanger Stelsel, VOC, Forced Coffee Planting, Cirebon, Periangan

\section{ABSTRAK}

Tulisan ini memberikan gambaran tentang sejarah kebijakan VOC (Verenigde Oost Indische Compagnie) yang disebut dengan Preanger Stelsel. Kebijakan ini mulai digulirkan oleh VOC pada tahun 1707 di wilayah Cirebon-Priangan. Kebijakan yang kerap disebut juga dengan sistem tanam paksa kopi ini diterapkan oleh VOC sebagai penanda semakin kokohnya dominasi ekonomi VOC atas Kesultanan Cirebon yang jalannya telah dimulai sejak tahun 1681.

Dalam menjalankan kebijakannya, sebagai dasar operasionalnya, VOC menjalankan suatu sistem ekonomi yang sudah diterapkannya yang disebut sebagai Verplichte Leverantien, yakni penyerahan wajib atas dasar harga yang menguntungkan kompeni. Selain itu, VOC sebagai penguasa politik yang membawahi bupati-bupati takluk, tidak berbeda dengan raja, merasa berhak untuk memungut sebagian hasil bumi dan tenaga kerja dari rakyat taklukannya sebagai jatah persembahan berkala. Persembahan wajib yang bersifat pungutan berkala tahunan ini disebut Contingenten. Berbeda dengan Verplichte Leverantien, dalam Contingenten ini terdapat adanya unsur hak kedaulatan yang mendasarinya. Walaupun sesungguhnya sangat berlainan sifat dan dasar hukumnya antara Verplichte Leverantien (yang lebih bersifat hukum perdata) dan Contingenten (yang bersifat hukum publik), namun dalam pelaksanaannya antara kedua penyerahan wajib itu sulit untuk dibedakan, karena Verplichte Leverantien ada kalanya dijalankan tanpa adanya pembayaran, sedang Contingenten bisa saja terjadi dengan disertai imbalan sebagai ongkos pengumpulan atau upah pungut.

Melalui kebijakan tanam paksa kopi ini, VOC memperoleh keuntungan yang luar biasa dari kawasan Cirebon-Priangan sampai pada akhir abad ke-18. Di bawah pengaruh sistem itu, penduduk menjadi terputus kebebasannya dalam mencari sumber kehidupannya. VOC sebagai penguasa mengambil hak kepemilikan tanah dan mengklaim hak atasnya, dengan menuntut tenaga petani melalui para Bupati sebagai perantara. Namun demikian, para petani

Tamaddun: Jurnal Sejarah dan Kebudayaan Islam, Volume (8), Issue (2), Desember 2020 
tidak tinggal diam menghadapi kebijakan ini. Dengan caranya mereka melakukan pembangkangan. Diantaranya mereka menolak untuk menyetorkan hasil panen atau hanya sebagiannya saja yang menjadi kewajiban mereka. Mereka lakukan dengan membuang hasil panen itu atau menguburnya untuk menjaga agar jangan sampai dibawa ke gudang. Mereka menghindari kewajiban mereka. Ada pula yang menyerahkan kepada tengkulak yang memberi harga lebih tinggi dibanding VOC.

Kata Kunci: Preanger Stelsel, VOC, Tanam Paksa Kopi, Cirebon, Periangan

\section{Pendahuluan}

Pada hakekatnya, VOC (Verenigde Oost Indische Compagnie) didirikan dengan tujuan tidak lain kecuali berdagang. Demi kepentingan usaha dagangnya, hal yang paling esensial adalah upaya intervensi VOC terhadap penguasa lokal (raja dan bupati), pertamatama lewat jalur politik dengan menggunakan kewenangan dan kekuasaan mereka. Lalu, meminjam tangan penguasa lokal itu untuk menguasai sektor-sektor ekonomi adalah pilihan yang paling masuk akal. Untuk kepentingan ini, karenanya politik yang dijalankan VOC adalah mengalihkan dan memindahkan kekuasaan para penguasa lokal dan loyalisnya kepadanya. Demikianlah, pengaruh yang mulamula disemai lewat perjanjian dengan sultan-sultan Cirebon merupakan strategi pembukanya. Melalui perjanjian-perjanjian ini, di samping melakukan intervensi kebijakan politik, VOC juga mulai menguasai dan mendominasi sektor-sektor penting perekonomian Kesultanan Cirebon, seperti bea cukai, ekspor impor dan yang paling strategis adalah proses produksi dan penyerahan hasil produksi pertanian sebagai komoditas utama.

Perjanjan pertama tahun 1681 merupakan tonggak penguasaan itu. Perjanjian itu mewajibkan sultan-sultan Cirebon menerima VOC sebagai pelindungnya. Pengakuan ini diwujudkan dalam bentuk pembangunan benteng, penyerahan keuntungan dagang dak hak atas wilayah di sekitarnya. Sultan tidak diperkenankan ikut campur dalam perdagangan apapun dengan orang Makassar, Melayu, bangsa Mor, atau bangsa manapun juga. Penduduk tidak boleh berlayar lebih jauh dari Bali dan Borneo dan itu pun harus membawa kartu pas dari VOC. (Breman, 2014: 57). Perjanjian tahun 1685 dan 1688

Tamaddun: Jurnal Sejarah dan Kebudayaan Islam, Volume (8), Issue (2), Desember 2020 
menunjukkan secara lebih jelas motif kepentingan penguasaan ekonomi melalui kontrak politik tersebut. Misalnya, disebutkan bahwa pergantian syahbandar ditentukan dan diangkat oleh kompeni (pasal 7 dan 18), Tumenggung Raksanagara hanya boleh mengurus pendapatan hasil tanah dan pembagian selanjutnya diurus oleh kompeni (pasal 7 dan 17), Tumenggung Raksanegara juga tidak boleh mencampuri urusan Cina, pabrik arak dan urusan pribadi, dan semuanya diserahkan kepada Cina Sinko yang berfungsi sebagai kepala profesi yang ditunjuk oleh kompeni (pasal 19), dan mengurus kesejahteraan rakyat harus berdasarkan saran kompeni (pasal 20).

Benteng VOC pertama di Cirebon dibangun pada tahun 1686 di kawasan pelabuhan Cirebon, yang diberi nama De Fortrese de Bescherming (Benteng Perlindungan). Selain sebagai benteng, loji ini juga difungsikan sebagai tempat tinggal dan kantor Residen. (Raffles, II, 1982: 450). Sejak menanamkan pengaruhnya di Cirebon, mulai tahun 1685 pejabat kompeni di Cirebon disebut Residen. Pejabat kompeni pertama yang menempati benteng tersebut adalah Marten Samson sebagai Residen Cirebon pertama (1685-1688). Residen bertugas sebagai penghubung antara Pemerintah Tinggi kompeni di Batavia dengan para penguasa pribumi setempat. Di samping menengahi masalah penduduk, Residen juga bertugas menyelesaikan perselesihan antara pangeran atau sultan. Jika salah seorang sultan wafat, Residen harus segera pergi ke dalem untuk mengambil keris dan cincin bersegel yang diberikan pemerintah tinggi kompeni untuk kemudian diserahkan kepada pengganti takhta berikutnya dengan disertai upacara khidmat dan dilengkapi dengan akte pengangkatan yang disampul beludru berwarna kuning (Molsbergen, 1931: 37).

Dari benteng inilah VOC mengatur segala strategi dan pelaksanaan sistem ekonomi yang akan diterapkan di Cirebon, daerah koloninya. Setelah menguasai elit kekuasaan melalui kontak-kontrak politik, langkah berikutnya adalah menanamkan pengaruh dan kekuasaan pada kelompok penguasa pribumi pada level yang lebih rendah, yakni para bupati dan bawahan-bawahannya. Mereka menunjuk kepala pribumi (bupati dan bawahannya) sebagai layaknya pegawai kontrakan untuk kepentingan dominasi ini. Mereka bertanggungjawab atas pelaksanaan sistem setoran wajib. VOC sendiri tidak ikut campur tangan langsung dengan masyarakat petani. Bagaimana para kepala pribumi itu melaksanakan perintah yang

Tamaddun: Jurnal Sejarah dan Kebudayaan Islam, Volume (8), Issue (2), Desember 2020 
diterimanya dan permasalahan apa yang dihadapi merupakan urusan yang jauh di luar jangkauan pandang VOC. Dalam praktek dominasi ini, VOC memanfaatkan sistem dominasi raja kepada bawahannya yang sebelumnya telah berjalan. Namun, pada posisi para kepala terjadi perubahan yang drastis sehingga peran mereka secara nyata menjadi berbeda dari para pendahulunya. Jika sebelumnya mereka tunduk kepada penguasa yang jauh, sekarang mereka benar-benar harus mematuhi penguasa yang membawahi mereka dan yang terutama memanfaatkan mereka untuk kepentingan ekonomis (Breman, 2014: 73). Aliansi ini memberikan monopoli atas produksi pada Belanda dan keuntungan serta dukungan politik bagi priyayi setempat baik terhadap rakyat maupun terhadap keraton. Sedangkan raja dibantu dalam menghadapi penguasa setempat atau saingansaingan lain dari kalangan keluarga raja atau priyayi (Onghokham, 1983: 95)

\section{Pengaruh VOC di Cirebon: dari Intervensi Politik ke Dominasi Ekonomi}

Demikianlah, setelah 'menaklukkan' sultan-sultan Cirebon dengan perjanjian-perjanjian itu, VOC mulai menguasai para bupati sebagai penguasa takluk untuk memenuhi kepentingan dominasi ekonominya. Bupati bersama jaksa, dan ketib yang membentuk piramida bangsawan adalah atasan dari para kepala di lapisan yang lebih bawah. Dari lapisan bawah itu yang terpenting mengepalai urusan distrik. Distrik ini juga kesatuan teritorial yang dibentuk oleh VOC. Dalam satu distrik terdapat beberapa desa dengan satu atau paling banyak dua kepala: di desa besar seorang kuwu atau mantri dan prenta atau petinggi, sedangkan di pemukiman yang lebih kecil berpenduduk enam sampai sepuluh keluarga diangkat seorang prenta atau lurah. Semua pedukuhan atau kampung berpenduduk sedikit melebur dengan desa sekitar yang lebih besar terdekat dan penduduknya juga harus pindah kesana. Dengan rancangan seperti ini politik teritorial VOC mencapai dasar masyarakat petani. Pemerintahan di pusat distrik dirancang berdasarkan gagasan yang sama dengan pusat kabupaten, meskipun dengan kelengkapan yang lebih sederhana (Breman, 2014: 42).

VOC mulai menerapkan kekuasaannya dengan memutuskan hubungan antara kepala penduduk dengan majikan sebelumnya.

Tamaddun: Jurnal Sejarah dan Kebudayaan Islam, Volume (8), Issue (2), Desember 2020 
Pergantian pengabdian ini berjalan melalui proses panjang dan penguasa baru mendapatkan legitimasi secara perlahan. Untuk menjaga pengaruhnya dan menghindari persekongkolan antara para kepala penduduk dan cengkraman kekuasaan mereka, VOC mendorong para kepala untuk memberikan informasi tentang sesamanya sehingga timbullah kedengkian antar mereka (De Haan, 1910 I: 342). Pengerahan tenaga petani yang efektif dan menguntungkan tidaklah mungkin tanpa melibatkan para kepala. Jika melewatkan mereka akan menimbulkan persoalan dan sabotase berkepanjangan. Dalam resolusi tahun 1695 Pemerintah Tinggi (Hooge Regeering) memerintahkan para kepala untuk menyetor berbagai barang (De Haan 1912 III: 399).

Sebagai dasar operasional kekuasaan ekonominya, VOC menjalankan suatu sistem ekonomi yang disebut sebagai Verplichte Leverantien, yakni penyerahan wajib atas dasar harga yang menguntungkan kompeni. Selain itu, VOC sebagai penguasa politik yang membawahi bupati-bupati takluk, tidak berbeda dengan raja, merasa berhak untuk memungut sebagian hasil bumi dan tenaga kerja dari rakyat taklukannya sebagai jatah persembahan berkala. Persembahan wajib tahunan ini lazimnya berupa padi dan hasil pertanian rakyat lainnya, akan tetapi ada juga berupa hasil hutan, dan lain-lain pada dasarnya tanpa suatu pembayaran harga. Persembahan wajib yang bersifat pungutan berkala tahunan ini disebut Contingenten, suatu istilah yang mengandung makna adanya suatu penetapan jumlah (jatah tahunan) tertentu yang harus dipenuhi (Niel, 2003: 205). Berbeda dengan Verplichte Leverantien, dalam Contingenten ini jelas adanya unsur hak kedaulatan yang mendasarinya. Walaupun sesungguhnya sangat berlainan sifat dan dasar hukumnya antara Verplichte Leverantien (yang lebih bersifat hukum perdata) dan Contingenten (yang bersifat hukum publik), namun dalam pelaksanaannya antara kedua penyerahan wajib itu sulit untuk dibedakan, karena Verplichte Leverantien ada kalanya dijalankan tanpa adanya pembayaran, sedang Contingenten bisa saja terjadi dengan disertai imbalan sebagai ongkos pengumpulan atau upah pungut. Kaburnya perbedaan antara kedua jenis penyerahan wajib tersebut sudah barang tentu tidak lepas dari ketidak tegasan pemisahan status ganda VOC sendiri sebagai badan hukum perdata (pengusaha) di satu pihak dan sebagai badan hukum publik (penguasa) di lain pihak. Makin mapan kekuasaan VOC sebagai penguasa, maka Verplichte

Tamaddun: Jurnal Sejarah dan Kebudayaan Islam, Volume (8), Issue (2), Desember 2020 
Leverantien cenderung dikelola sebagai Contingenten (Sa'ban, 1988: 64). Dalam pelaksanaan persembahan wajib ini, para bupati bertanggungjawab sebagai penguasa takluk untuk menagih jatah pungutan itu dari rakyatnya dan menyetorkan kepada kompeni sbagaimana dahulu mereka mengelola 'pajeg bumi' untuk para sultan.

Sebelum diterapkan oleh VOC, kewajiban pungutan dan kerja itu pada awalnya muncul karena adanya kewajiban penyerahan sebagian produksi padi oleh petani pemilik lahan kepada juragannya. Pemungutan ini berdasarkan perintah kepala distrik. Dalam pengumpulannya pemuka agama desa ikut terlibat. Pelibatannya itu timbul akibat peran yang dimainkan oleh kalangan pemuka agama yang lebih rendah dalam pengaturan pekerjaan pertanian: waktu penyemaian di sawah, pengelolaan pengairan dan sebagainya. Sepertiga dari cukai itu diperuntukkan bagi para kepala rendahan yang paling dekat dengan petani. Tetapi bagian yang diperuntukkan bagi bupati tidak langsung diserahkan, padi tetap disimpan di lumbung sampai ada perintah penyerahan. Pemilik sawah pada umumnya harus menyerahkan sepersepuluh bagian (Breman, 2014: 45-46)

Selain menerapkan sistem monopoli ekonomi, dalam rangka usaha untuk meningkatkan penghasilannya, VOC melakukan hal yang sangat tidak populer, mereka menerima masuknya pedagangpedagang Cina ke desa-desa di pedalaman dan bahkan menyewakan desa-desa dan kabupaten-kabupaten kepada orang Cina kaya yang kuat membayar mahal kepada Sultan karena tahu bagaimana caranya memeras beras sebanyak mungkin dari penduduk desa (Vlekke, 1959: 236). Dalam sistem persewaan desa itu, desa-desa yang disewakan beserta penduduknya menjadi objek milik pribadi para penyewa. Para penyewa bisa menuntut berbagai kewajiban dari penduduk dan pejabat setempat karena ia berada di bawah penguasaan langsung VOC, misalnya pengambilan pajak, penerimaan kerja wajib, penyerahan wajib dan monopoli perdagangan. Mereka menjadi tuan tanah yang memiliki hak untuk menguasai penduduk yang hidup diatas tanah desa tersebut dan menuntut pengerahan tenaga beserta hasil tanahnya, bahkan bisa minta apa saja yang dikehendakinya. Mereka dapat menarik pendapatan dari desa-desa, menuntut penyerahan sejumlah tertentu beras atau jasa-jasa lain sebagai pajak

Tamaddun: Jurnal Sejarah dan Kebudayaan Islam, Volume (8), Issue (2), Desember 2020 
(pajeg), cukai (cuke) dan kerja wajib (contingent). Disamping itu, mereka yang mengolah tanah berkewajiban untuk melakukan kerja kompenian (kerja paksa) selama lima hari setiap bulan, kerja garol (tiga hari setiap bulan), kroyo (untuk setiap laki-laki yang masih kuat, dan tugas kemit (perondaan desa) (Poesponegoro 1990: 283-285).

Tuan-tuan tanah itu adalah para pengusaha swasta kaya yang diberikan hak menyewa desa oleh pemerintah. Pada umumnya mereka terdiri dari sebagian kecil orang-oranag Eropa, Arab, dan sebagian besar orang-orang Cina ${ }^{1}$ (Vlekke 1959: 222). Kebijakan tentang persewaan desa $^{2}$ ini dilakukan oleh pemerintah sebagai bagian dari cara untuk menambah keuangan negara dan mengeruk keuntungan sebesar-besarnya dari tanah jajahan. Penyewaan desa kepada pihak 'pemborong pajak' (pachter) swasta umumnya orang Cina juga dilakukan oleh para Bupati untuk jangka waktu tertentu. Dengan membayar di muka uang sewa atau borongan, maka penyewa memperoleh hak-hak tertentu dari penguasa, seperti hak memungut berbagai penghasilan Negara dan hak atas tenaga kerja penduduk. Dengan menyewakan desa atau kompleks desa-desa, maka pemasukan pungutan-pungutan Pemerintah terjamin dan kebutuhan akan uang tunai terpenuhi. Bahwa terjadi penyalah gunaan kekuasaan oleh para penyewa yang hendak memperoleh keuntungan sebesar-besarnya, bukanlah hal aneh dan rakyatlah yang menjadi korban. Orang-orang Cina dan Eropa penyewa desa umumnya menggunakan tanah dan tenaga kerja desa dengan cara seperti itu untuk memperoleh komoditas ekspor. Semuanya menggunakan tenaga kerja paksa, yakni kerja yang dilaksanakan sesuai dengan pola-pola kewajiban tradisional, dan bukan kerja bebas yang menurut pengertian waktu itu dijalankan demi mendapatkan upah berupa uang (Niel, 2003: 168).

\footnotetext{
${ }^{1}$ Dominasi orang-orang Cina ini disebabkan karena posisi 'istimewa' mereka dengan VOC yang telah terjalin lama. Dari mulanya, antara VOC dan orang-orang Cina memang memiliki saling pengertian bahwa kedatangan mereka ke Jawa adalah karena alasan ekonomi, terutama alasan perdagangan. Karenanya, orang-orang Belanda segera berpaling kepada mereka sebagai partner dagangnya yang utama (Onghokam 1991: 33)

${ }^{2}$ Kebijakan ini telah berlangsung cukup lama dan menjadi kian massif pada akhir abad ke18. Menurut catatan D.H. Burger, pada tahun 1796, di kawasan pantai Timur Laut Jawa, setidaknya ada 1.134 desa yang disewakan, dan pada tahun 1803, jumlah itu semakin membengkak menjadi 1.446 desa atau 9\% dari 16.083 desa (Burger 1962: 103).
}

Tamaddun: Jurnal Sejarah dan Kebudayaan Islam, Volume (8), Issue (2), Desember 2020 


\section{Preanger Stelsel; Sistem Tanam Paksa Kopi di Cirebon-Priangan}

Dominasi ekonomi VOC atas Cirebon semakin mantap setelah diberlakukannya sistem tanam paksa kopi di wilayah CirebonPrinagan pada awal abad ke-18. Sebagai perusahaan terbuka, keberlangsungan VOC sangat bergantung pada keuntungan yang dapat diberikan kepada pemilik saham. Hal itu dapat dipenuhi dengan cara mempertahankan harga tinggi, meningkatkan volume perdagangan, atau beralih kepada komoditas yang lebih menjanjikan keuntungan. Pilihan pertama berjalan pada masa awal perushaan didirikan, yakni perdagangan rempah-rempah. Pilihan kedua telah dicoba pada periode 1680-1725. Alternatif ketiga yaitu beralih pada komoditas yang lebih menjanjikan. Komoditas yang dimaksud adalah kopi. Dikarenakan tingginya harga di pasar Eropa, VOC mencoba mendapatkan keuntungan melalui perdagangan kopi. Tidak seperti komoditas dagang yang sebelumnya diperdagangkan oleh VOC, kopi merupakan sesuatu yang asing dalam sistem pertanian di Jawa (Hoadley, 1994: 134).

Ide mengenai pembudidayaan kopi sendiri sebenarnya bermula dari sesuatu yang barangkali terbilang agak remeh, yakni kecintaan orang Belanda abad ke-18 terhadap pertamanan. Salah satu aspeknya ialah minat terhadap bunga dan tanaman eksotik. Sekitar tahun 1700, ada pejabat-pejabat tinggi di Hindia yang sama-sama punya hobi bertaman di rumah. Kelompok kecil hortikulturalis Batavia $^{3}$ ini termasuk dua Gubernur Jenderal dan beberapa anggota dewan, Johan van Hoorn salah satunya. Di tanahnya yang luas di perdesaan dekat Batavia dia bereksperimen dengan banyak tanaman non-Indonesia. Di antara tanaman-tanaman itu terdapat beberapa pohon kopi kecil yang dikirimkan kepada van Hoorn dari pantai barat India. Pada waktu itu, van Hoorn tentu tidak dapat

\footnotetext{
${ }^{3}$ Ini adalah kelompok di sekitar Gubernur Jenderal Johannes Camphuijs (1684-1691). Pieter van Hoorn (1682) menyarankan kolonisasi skala besar. Puteranya, Johan, di bawah bimbingan Cornelis Speelman, menjadi ahli dalam urusan pribumi. Cornelis Chastelein, teman Camphuijs yang lain, mendirikan permukiman di Depok. Baik Johan van Hoorn maupun Chastelein mengambil bagian penting dalam promosi kultur kopi. Semua orang ini, yang punya minat sangat besar pada urusan Hindia Timur adalah pemilik tanah. Johan van Hoorn, Gubernur Jenderal 1704-1709 adalah pemilik tanah terbesar di Batavia. Hendrik Zwaardecroon, Gubernur Jenderal 1718-1725 adalah orang yang menyediakan bagi van Hoorn pohon kopi muda dari pantai Malabar.
}

Tamaddun: Jurnal Sejarah dan Kebudayaan Islam, Volume (8), Issue (2), Desember 2020 
membayangkan bahwa eksperimennya membuka jalan untuk revolusi ekonomi dan sosial yang akan mengubah nasib penduduk Jawa. Pohon-pohon kopi van Hoorn tidak tumbuh subur di tanah asing di Jawa. ${ }^{4}$ Zwaardecroon, Gubernur Jenderal yang selanjutnya, dan Chastelein meneruskan eksperimen itu dengan lebih berhasil dengan bantuan Witsen, seorang kepala hakim yang menangani perkara kecil (burgomaster) Amsterdam sekaligus direktur VOC. Witsen, yang juga masih kerabat van Hoorn, mendapatkan untuk teman-temannya di Batavia suatu perintah oleh para direktur untuk meneruskan usaha mereka, dengan janji hadiah kalau eksperimen mereka berhasil memungkinkan produksi tanaman-tanaman baru yang bernilai komersil di Jawa. (Vlekke, 1959: 216).

Demikianlah, pada tahun 1707 tanaman kopi mulai dibagibagikan di kalangan para kepala daerah di sekitar Batavia dan Cirebon. Namun, ternyata di dataran rendah buah kopi tidak begitu berkembang. Ketika dipindah pertama-tama ke perbukitan Krawang kemudian ke daerah yang lebih tinggi, ternyata mendatangkan hasil yang lebih baik (Breman, 2014: 61). Hal ini terutama karena kopi merupakan tanaman perdu yang memerluka iklim sedang, sehingga di dareah beriklim tropis seperti Jawa, hal itu hanya dapat diperoleh pada daerah dengan ketinggian 650-1600 mdpl. Dengan curah hujan $1500 \mathrm{~mm}$ per tahun, memiliki drainase yang baik, terlindung dari angin, intensitas sinar matahari tinggi dan pengaruh hujan tropis. Tanah pada hutan alami merupakan kondisi yang optimal sebab memiliki kandungan humus yang tinggi, meskipun hai itu tidak terlalu berpengaruh sebab tanah vulkanik Jawa memiliki kandungan nitrat yang tinggi. Persayaratan terakhir adalah bentuk dari terasan, sebab tanaman ini memerlukan drainase yang baik.Teras yang terlalu curam menyebabkan tingginya aliran permukaan dan mengakibatkan banyak kandungan hara terbawa aliran, sedangkan jika terlalu datar dapat menyebabkan akar tanaman terendam (Hoadley, 1994: 135).

Pada tahun 1711, $50 \mathrm{~kg}$ pertama panen kopi diserahkan ke gudang kompeni oleh Arya Wiratana, bupati Cianjur. Sembilan tahun kemudian panen tahunan meningkat menjadi 45 ton dan setelah 12 tahun produksi mencapai 5.500 ton (Vlekke, 1959: 217). Pembukaan lahan perkebunan kopi baru memberikan hasil luar biasa, pada tahun

\footnotetext{
${ }^{4}$ Impor kopi pertama dari Arabia ke Belanda dilakukan pada 1663. Van Hoorn mengirimkan beberapa pohon kopi ke Amsterdam, dan dari situ benih dikirim ke Hindia Barat. 
1713 Cirebon menghasilkan 150 kilogram, pada tahun 1730 meningkat menjadi 375.000 kilogram dan pada tahun 1823 menghasilkan lebih dari 650.000 kilogram.(DH. Burger: 1962: 239-242). Alhasil, pembudidayaan kopi ini meluas dengan cepat terutama menyebar ke pedalaman Batavia, dataran tinggi Priangan. VOC menjadi penyalur terpenting untuk produk kolonial baru ini. Pada tahun 1726 setengah hingga tiga perempat dari perdagangan kopi dunia berasal dari VOC dan dari jumlah itu setengahnya dihasilkan dari Priangan bagian barat, yakni daerah Cianjur. Pada abad ke-18, kabupaten Cianjur, yang kolonisasinya diawali dari kabupaten Cirebon, berkembang menjadi gudang kopi terpenting bagi VOC (Breman, 2014: 61, 65). Pada tahun 1723 kopi dijadikan barang monopoli. Menjual kopi kepada pedagang swasta dapat dihukum. Pada tahun itu juga para direktur VOC menentukan jumlah pengeluaran tahunan 4 juta pon dan harga 12,5 gulden per pikul (Vlekke, 1959: 221).

\section{Intensifikasi Pembubidayaan Kopi}

Pembudidayaan kopi ini tidak menimbulkan banyak masalah karena kopi adalah tanaman yang tidak memerlukan modal, peralatan mahal dan hanya membutuhkan sedikit pengetahuan (de Haan, 1910 I: 119). Namun demikian, sebagai jenis tanaman baru dan dengan sistem baru, memperkenalkannya sebagai metode produksi yang baru bukanlah hal mudah. Hal ini berarti, dalam jangka waktu yang lama, budidaya kopi akan memberikan berbagai dampak terhadap masyarakat Jawa. Pertama, kebutuhan pada lingkungan baru bagi tanaman kopi harus dibuat dalam sistem pertanian. Tanaman kopi tidak dapat tumbuh dalam areal yang memiliki aspek ekologi seperti gaga atau sawah. Kopi memerlukan lahan dengan terasan kering yang permanen, dalam iklim yang spesifik. Kedua, ketersediaan buruh perkebunan yang harus dikelola secara effektif dan perubahan ke arah teknik-teknik baru untuk budidaya tanaman yang benar-benar baru dikenal, dilengkapi dengan kebutuhan proses pasca panen untuk memperoleh produk akhir untuk ekspor, berupa biji kopi kering berkualitas dan dikemas secara baik. Terakhir, tidak adanya alat transportasi yang efektif, sehingga untuk memenuhi kebutuhan beras bagi buruh di perkebunan kopi, harus menanam padi di lahan sekitar perkebunan. Konsentrasi penduduk di suatu lokasi dihadapkan dengan peningkatan perminataan beras sebagai

Tamaddun: Jurnal Sejarah dan Kebudayaan Islam, Volume (8), Issue (2), Desember 2020 
komoditas ekspor yang tidak mampu terpenuhi dengan sistem produksi yang ada (Hoadley, 1994: 135).

Kebun-kebun kopi dibuat di atas tanah-ranah liar dengan memanfaatkan kerja wajib. Penanaman kopi diserahkan pengawasannya kepada Bupati. VOC mengawasi bupati-bupati untuk menjaga kepentingannya agar terpenuhi. (D.H. Burger, 1962: 114). Penduduk wajib menanam dan menyetor kopi atau produk lain ke tempat pengumpulan yang ditunjuk dan ditambah wajib membangun gudang, membuat jalan, dan pekerjaan lainnya yang diperintahkan oleh VOC, yang kemudian disebut vultuurdiensten (tugas kerja pada budidaya) mencakup baik penanaman maupun penyetoran tanaman tertentu. Di samping itu masih ada kerja pengabdian bagi para kepalanya sendiri. Yang terpenting dalam kerja pengabdian ini adalah menyisihkan sebagian dari panen padi dan bebas menggarap lahan yang dikelola bangsawan pribumi sendiri. Kegitannya meliputi berbagai tugas pekerjaan di rumah atau pekarangan rumah atasannya. Pada akhirnya bupati berhak memungut berbagai pajak tambahan di wilayah kekuasaannya -tol, pungutan pasar, pembayaran kartu pas, pajak pemotongan atau pernikahan, dan sebagainya- tanpa perlu memberikan alasannya (Breman, 2014: 69).

Rakyat digerakkan oleh petugas desa untuk membuka lahan. Pekerjaan ini mengharuskan mereka untuk meninggalkan keluarga selama beberapa bulan lamanya. Setelah proses penanaman, selama tiga tahun pertama kebun kopi harus disiangi dari rumput-rumput liar dan dicangkul sebulan sekali. Selama panen mereka harus tinggal didekat perkebunan untuk memetik buah kopi yang matang tidak bersamaan dan untuk menjaga perkebunannya dari pemetik liar. Kopi yang telah dipetik dibawa ke desa-desa untuk disiangi dan dijemur sampai kering dan akhirnya dibawa untuk diserahkan kepada bupati. Dari awal penanaman pengiriman tersebut, seluruh biaya dikenakan kepada rakyat petani. Mereka menerima upah sebesar f. 17 setahun untuk seluruh jasa mereka. (D.H Burger: 1962: 245-249).

Dalam rangka agar sistem budidaya kopi ini berjalan sesuai harapan dan untuk meningkatkan pengawasan atas para kepala, VOC mengangkat pejabat dengan pangkat Gecommitteerde tot de Saecken der Inlanderen (Komitir untuk Urusan Pribumi) yang disingkat menjadi Commisaris (Komisaris) atau Landscommisaris (Komisaris Negeri) (de

Tamaddun: Jurnal Sejarah dan Kebudayaan Islam, Volume (8), Issue (2), Desember 2020 
Haan, 1912 IV: 1304). Pejabat ini merupakan bawahan langsung gubernur-jenderal yang mengurus masalah dalam negeri. Meskipun untuk jabatan ini tidak pernah ditetapkan instruksi resmi, namun beban kebutuhan itu semakin meningkat. Sejak tahun 1730 semua korespondensi dengan bupati melalui komitir. Ia bertindak sangat mandiri dan mengambil keputusan yang memiliki wewenang tinggi: perubahan batas kabupaten, pembebasan atau malah penerapan tanam paksa di distrik-distrik, pembukaan daerah pedalaman dengan pembangunan infrastruktur, dan sebagainya. Pada tahun 1745 keluar instruksi yang menyatakan bahwa di saat komitir mengunjungi pospos luar, harus diberi penghormatan militer. Naiknya penghargan jabatan ini dalam hirarki VOC terutama disebabkan karena meningkatnya arti tanaman kopi bagi VOC (Breman, 2014: 74).

Komitir hanya menerima bayaran kecil dari VOC yang dari bayaran itu ia juga harus membayar staf pengawas dan penjaganya. Meski demikian, penghasilannya terus meningkat hingga mencapai jumlah yang di luar batas. Penghasilan itu ia dapatkan berkat sistem pengupahan yang tidak menyimpang dari yang terjadi pada masa prakolonial. Sebagian penghasilannya didapat dari penanaman dan perdagangan, seperti komisi pembelian kopi dan penjualan candu serta pungutan di pasar dan pertunjukan. Di samping itu, ia juga menerima bayaran besar dari pra bupati dan kepala bawahannya atas kerelaannya bekerja sama. Bangsawan pribumi tetap meneruskan kebiasaan seperti yang dilakukannya bagi raja: membagikan hadiah pada acara pengangkatan atau promosi dalam rangka tahun baru, pada kunjungan ke Batavia, dan pada waktu menerima bantuan, serta lainnya yang tersamar antara tanda penghormatan atau penyogokan uang. Karena uang muka itu para bupati terikat sepenuhnya pada komitir. Sudah biasa jika komitir tanpa sepengetahuan bupati membayar sesuatu atas namanya. Seorang bupati yang baru diangkat akan mendapat bukti pengangkatan setelah ia membuat pernyataan tertulis mengambil alih hutang pendahulunya dan di samping itu juga masih menjamin kewajiban para kepala lain. Dengan latar belakang ini, tidaklah mengherankan jika sebagian besar uang yang seharusnya untuk membayar produk yang diperoleh secara paksa, tidak pernah meninggalkan Batavia. Bupati berfungsi sebagai pemasok kopi sebenarnya. Dalam peraturan pembayaran di muka, ia menerima sepertiga jumlah pembayaran akhir. Dari sisanya setengahnya digunakan untuk ongkos pengangkutan, sedangkan 
setengahnya lagi untuk kebutuhan pembayaran petani. Pembagian itu hampir tidak pernah berubah, dengan syarat bahwa pembayaran kepada pihak yang paling bawah dari rangkaian itu tetap menjadi sisa (Breman, 2014: 76-77).

\section{Sang Opziener Itu Bernama Pangeran Aria}

Sementara itu, untuk mengawasi kinerja para bupati di Priangan, melalui Resolusi Tanggal 9 Februari 1706, VOC mengangkat putera kedua Sultan Sepuh I, Pangeran Aria Adiwijaya (Kartodirjo, 1987: 246) atau Pangeran Aria Gede Adiwijaya alias Abimukharam Muhamad Khaharudin sebagai Opziener der Cheribonsche Preangerlanden (Pengawas Tanah Cirebon-Priangan) atau pengawas para Bupati di Priangan. Daerah kekuasaannya meliputi: Limbangan, Sukapura, Galuh, Bandung, Parakanmuncang, Sumedang, Ciasem, Pamanukan, dan Pegaden. Daerah kekuasaannya tidak termasuk untuk Bupati Karawang dan Cianjur. Kedua wilayah ini sudah dianggap sebagai bagian dari Batavia sehingga para bupatinya langsung diawasi oleh pejabat-pejabat VOC. Jabatan pengawas (opziener) yang diperkenalkan oleh VOC ini dapat dipersamakan dengan jabatan wedana-bupati pada zaman Mataram. Tugas utamanya adalah mendampingi residen dalam mengawasi kinerja para Bupati. Pengangkatan ini dilatarbelakangi oleh adanya hubungan yang kurang baik antara residen dengan para Bupati dan intensitas konflik antar Bupati (Molsbergen, 1931: 9)

Pengangkatan Pangeran Aria sebagai opziener juga merupakan strategi Kompeni untuk mengambil keuntungan dari tanah Priangan yang telah didapatkan dari penguasa Mataram, karena pada waktu kompeni menerima penyerahan daerah priangan timur (Limbangan, Sukapura dan Galuh) dari Mataram berdasarkan traktat 1705, daerah itu tidak langsung ditempatkan dibawah pemerintahan kompeni, tetapi dikuasakan kepada Cirebon. Berdasarkan surat keputusan Pemerintah Tinggi Kompeni tanggal 13 November 1705, pengawasan seluruh daerah Priangan dipercayakan kepada Pangeran Aria Cirebon. Pengangkatan Pangeran Aria Cirebon dikukuhkan lagi dengan surat keputusan tanggal 9 Februari 1706. Berdasarkan surat keputusan tersebut, Pangeran Aria Cirebon diangkat sebagai opziener untuk memerintah bersama-sama residen yang berkedudukan di

Tamaddun: Jurnal Sejarah dan Kebudayaan Islam, Volume (8), Issue (2), Desember 2020 
Cirebon. Jabatannya sebagai Opzigter ditetapkan lagi dengan surat keputusan tanggal 22 Maret 1706 (Haan, III, 1912: 245).

Dalam akta pengangkatannya itu Pangeran Aria Cirebon mendapat perintah untuk menjalankan sistem pemerintahan tradisional atas nama VOC di daerah Priangan dan Galuh. Dalam melaksanakan tugas sehari-harinya ia didampingi oleh Residen Cirebon dan Letnan Caspar Lippius. Pada tanggal 22 Maret 1706, VOC mengeluarkan empat kewajiban utama yang harus dijalankan oleh Pangeran Aria Cirebon sebagai Wedana-Bupati Priangan. Pertama, menjaga perdamaian antara para bupati dan mencegah adanya perebutan penduduk. Kedua, mendorong penanaman padi. Ketiga, mewajibkan penyerahan kapas, indigo, dan lada dengan suatu pembayaran. Keempat, tidak boleh mengangkat patih tanpa persetujuan Residen Cirebon. (Haan, III, 1910: 250). Yang paling penting dari pengangkatan Pangeran Aria Cirebon sebagai pengawas Bupati adalah keterkaitannya dengan kebijakan Kompeni mengenai pembudidayaan kopi.

\section{Penutup}

\section{Bisnis Kopi; Belanda Untung, Petani Buntung}

Demikianlah, keberhasilan perekebunan kopi yang tak terduga mengguncang seluruh sistem sampai dasar-dasarnya. Budidaya kopi sangat menguntungkan VOC. Jumlah uang yang diterima oleh para bupati juga sangat meningkatkan penghasilan mereka. Besarnya jumlah kopi yang diproduksi membuat kontrol ketat atas ekspor mustahil dilakukan. Bahkan jika VOC menggunakan seluruh armada kapal patroli di sepanjang pantai Jawa, ia tidak bisa mencegah bertonton kopi diselundupkan. Ada aspek lain yang menggelisahkan mengenai perkara ini, paling tidak di mata para direktur. Pada tahuntahun pertama industri itu, ketika harga-harga masih sangat tinggi, beberapa penguasa daerah Jawa mengumpulkan jumlah uang yang besar. Mereka memaksa rakyat mereka menanam kopi tapi membayar sangat rendah untuk usaha mereka, sementara mereka sendiri menerima harga tinggi dari kompeni, sampai 50 gulden satu pikul (56 $\mathrm{kg})$. Di Eropa harga kopi saat itu dua gulden satu pon $(0,45 \mathrm{~kg})$. Jelas, hubungan ekonomi semacam ini membuat para penguasa daerah Jawa jadi bawahan paling setia yang bisa ditemukan Kompeni di

Tamaddun: Jurnal Sejarah dan Kebudayaan Islam, Volume (8), Issue (2), Desember 2020 
seluruh dunia, tapi juga membuat mereka berkuasa dan percaya diri. Karenanya, para direktur VOC mencari jalan lain untuk mempertahankan kebijakan komersial tradisional mereka (Vlekke, 1959: 219)

Pada tahun 1726, penguasa tertinggi memberlakukan secara drastis penurunan harga kopi di Batavia dari 50 menjadi 12 gulden per pikul. Penyebab yang mendasari keputusan ini adalah kekhawatiran akan cepat meluasnya pemanfaatan uang di kalangan penduduk. Pemanfaatan uang untuk hal yang bertentangan dengan kepentingan VOC, misalnya untuk pembelian senjata (Breman, 2014: 62). Kemudian, mereka memerintahkan pembatasan perluasan perkebunan. Untuk memaksa harga lebih turun lagi, pejabat Batavia memperkenalkan pembedaan canggih terhadap 'pikul gunung' sebesar $102 \mathrm{~kg}$ dan pikul Batavia seberat $56 \mathrm{~kg}$. Para produsen dipaksa menyerahkan jumlah kopi yang ditentukan dalam ukuran pikul gunung tapi menerima pembayaran dalam jumlah pikul Batavia yang sama. Perbedaan berat dijelaskan sebagai biaya pengeringan selama transportasi dari daerah-daerah pegunungan ke gudanggudang Batavia. Dengan memanipulasi jenis pikul yang berbeda para pejabat tersebut memperoleh ganti sangat memadai atas upaya mereka sendiri sekaligus atas kerugian kompeni (Vlekke, 1959: 219).

Dalam keadaaan seperti itu, tentu saja, para petani tidak bersemangat menanam kopi. Keuntungan terbatas tersebut, yang dengan murah hati diberikan kompeni kepada para produsen, berakhir di kantong para penguasa daerah. Untuk para petani, budidaya kopi ini tampaknya hanya mendatangkan beban tambahan, tanpa penghasilan tambahan. Keengganan mereka bekerjasama menjadi begitu kuat sehingga selama beberapa tahun kompeni bahkan tidak bisa memperoleh jumlah terbatas yang dituntutnya. Para petani mengabaikan kebun kopi mereka. Menyikapi pengabaian dan ketidakpedulian yang ditunjukkan para petani, VOC mengangkat seorang pengawas untuk membantu para bupati mengatur produksi dan mengontrol perawatan kebun kopi. Para pengawas ini dikenal dengan nama 'sersan kopi'. (Vlekke, 1959: 219). Mereka, yang kebanyakan tidak menguasai bahasa pribumi dan sebelum pengangkatannya tidak pernah melihat biji kopi, mengawasi dari jarak dekat perilaku bupati. Dalam teori, bupati adalah jabatan di atas

Tamaddun: Jurnal Sejarah dan Kebudayaan Islam, Volume (8), Issue (2), Desember 2020 
sersan kopi, di pedalam di sebut Tuan Mandor, dalam prakteknya bupati sering diperlakukan seperti bawahannya (Breman, 2014: 78).

Sekitar tahun 1760, penanaman tahunan sejumlah pohon kopi baru diharuskan. Seluruh budidaya itu diserahkan kepada para bupati, yang mengatur produksi sesuai dengan permintaan "Komisaris untuk Urusan Pribumi", seorang pejabat Belanda yang ditunjuk Gubernur Jenderal. Jika para bupati tidak mau bekerjasama dalam penyerahan kopi dengan jumlah tepat kepada kompeni sebanyak yang diinginkan untuk pasar eropa, mereka akan dipaksa menyerahkan jumlah itu dan memberikannya kepada kompeni dalam bentuk upeti sebagaimana upeti beras yang sebelumnya dibayarkan kepada raja, atau mereka dipaksa menjualnya dengan harga yang ditetapkan pemerintah, dan mengirimkannya dengan biaya sendiri ke gudang-gudang Batavia (Vlekke, 1959: 220-221).

Pada tahun 1764 diputuskan bahwa sepikul kopi untuk pengapalan harus 126 pon tapi untuk pembelian harus 140 pon. Perbedaan itu yang resminya untuk mengatasi pengeringan, nyatanya adalah untuk keuntungan bagi pegawai. Penambahan diperhitungkan lagi antara gudang lokal dan Batavia, yang dipatok pada tahun 1777 seberat 6 pon dan dengan seenaknya ditambah lagi berat 14 pon pada tahun 1797. Sehingga untuk setiap 126 pon yang dikapalkan, bupati harus menyuplai 160 pon, dan karena 14 pon adalah harga pembayaran untuk petani, taktik tahun 1797 itu memberikan kepada Kompeni kopi secara cuma-cuma. Para bupati mengikuti contoh Kompeni dan menentukan berat pikulan sewenang-wenang mulai dari 240 sampai 270 pon. Ujung-ujungnya untuk setiap pikul seberat 126 pon yang dikapalkan, petani kopi harus menyuplai 240 sampai 270 pon dan dibayar seharga 14 pon (Furnivall, 2009:43).

Pada tahun 1777 dipakai istilah bergse pikol (pikulan gunung). Hal ini berarti bahwa berat per pikul bagi petani kopi, tergantung kabupaten asalnya, berkisar antara 200 sampai 300 pon, sedangkan perhitungan dengan para bupati tetap berdasarkan ukuran lama, 146 pon per pikul. Dengan cara perdagangan licik ini, tentu saja, pendapatan petani menjadi sangat berkurang, tetapi kepada para bupati VOC tetap membayar dengan harga lama karena tanpa kerjasama mereka resiko perusahaan atas budidaya kopi akan sangat besar. Harga untuk ukuran berat yang dinaikkan tidak berubah, dan inilah motif sesungguhnya penyesuaian berat itu. Surplusnya masuk

Tamaddun: Jurnal Sejarah dan Kebudayaan Islam, Volume (8), Issue (2), Desember 2020 
ke kantong jajaran pimpinan VOC sendiri. Itu juga sebabnya mengapa berat per pikul bervariasi tegantung daerah asal setoran, di dataran pegunungan selalu lebih berat dibanding dataran rendah (Breman, 2014: 73).

Dalam mengatur pembudidayaan kopi ini, sistem pemerintahan yang diterapkan oleh VOC tidak menghendaki tumpang tindihnya dan penumpukan wewenang melalui pelbagai jalur tetapi satu dan yang lain tidak saling serasi. Hanya ada satu jalur komando dari bupati ke petani kopi. Sedangkan para kepala bawahan mendapat tugas yang lebih spesifik yang satu sama lain terkait dalam hubungan atas bawah. Dengan ini, berakhirlah hak yang dinikmati bangsawan pribumi dari dulu, yakni kebebasan mengakhiri keterikatannya dengan majikan. Seperti juga berlaku pada petani, VOC berharap pengabdian kepada kepala dilihat sebagai sesuatu yang tidak bisa diakhiri dan tidak bisa dialihkan. Larangan sepenuhnya tidak dapat dipaksakan dan sebagai jalan tengah diberlakukan peraturan yang mengatur bahwa bawahan selanjutnya jika pindah majikan harus meninggalkan hartanya (tanah dan juga pengikutnya) pada majikan lama (Hoadley, 1994: 147). Ini adalah suatu konsepsi aturan yang tanpa dasar, sebab beralih majikan tanpa diperbolehkan tanpa membawa pengikutnya adalah omong kosong. Hal itu sama halnya dengan meninggalkan modal yang terkait dengan kekuatan ekonomis dan status politis dari kepala yang bersangkutan. Aturan ini tentu saja merugikan para petinggi itu. Tetapi di sisi lain, aturan ini menjamin keamanan dan stabilitas lebih besar bagi posisi mereka. Mereka tidak perlu mengkhawatirkan adanya saingan yang hendak menggoyahkan basis kekuasaannya dengan memprovokasi bawahan agar membelot. Karenanya, dapat dipahami mengapa pada pertengahan abad ke-18 para pejabat tinggi Cirebon atas kemauan sendiri mendesak VOC untuk mencabut hak pemecatan mereka oleh Sultan (Hoadley, 1994: 125).

Dalam usahanya meningkatkan jumlah tanaman wajib, VOC menempuh cara memperluas pemungutan upeti di lapisan masyarakat bawah. Hal itu dilakukan melalui kewajiban kerja pada penanaman yang melibatkan bukan saja petani yang menetap di satu daerah (bumi), tetapi juga pendatang baru yang ikut tinggal (numpang). menurut pendapat umum kelompok terakhir ini adalah petani yang lari dari tempat lain untuk melepaskan diri dari tingginya

Tamaddun: Jurnal Sejarah dan Kebudayaan Islam, Volume (8), Issue (2), Desember 2020 
tuntutan majikannya. Majikannya yang baru juga memanfaatkan tenaga para numpang, untuk antara lain menggarap sawahnya dan sebagai imbalannya mereka mendapat sebagian hasil panen. Pada hakekatnya sebuah keputusan yang berdampak besar pada masyarakat, yang diambil dengan tujuan yang jelas. Peraturan itu memang bertujuan mewujudkan pemerataan beban wajib kerja bagi semua petani pada penanaman. Dalam konfigurasi ini tidak lagi tersedia ruang bagi keluarga petani yang terikat pada kepala setempat sebagai kesatuan pajak dan melalui kepala ini sebagai dampak pengabdian terikat pada bupati sebagai majikan sesungguhnya (Breman, 2014: 81).

L. Rolff, yang pada tahun 1789 diangkat menjadi Komitir, setahun kemudian mengusulkan agar setiap keluarga, baik numpang maupun bumi, di wilayah Jacatra-Priangan dan dataran tinggi secara merata dilibatkan dalam penanaman. Ketetapan itu dijadikannya pasal satu dalam Peraturan Kopi yang dikeluarkannya pada tahun 1789. Untuk penulisan pedoman penanaman kopi, Rolff mendapat dorongan sari surat Heren XVII pada tahun 1788 yang berisi bahwa kopi Jawa tidak terlalu banyak bisa dibudidayakan dan dihasilkan. Peraturan itu merinci pemilihan lahan, cara penanaman, perawatan pada masa pertumbuhan, dan pemetikan serta pengeringan biji kopi. Rolff menyusun instruksi ini berdasarkan daftar pertanyaan yang diajukan kepada para pengawas dan kepala pribumi. Hal yang mendorongnya menulis peraturan itu adalah niatnya melakukan perbaikan pada cara kerja yang ditemuinya. Ia prihatin dengan keadaan tanaman yang buruk hampir di semua tempat dan ia menyatakan bahwa bagi bupati yang tidak taat pada petunjuknya akan mendapat hukuman yang pantas. Penanaman harus sedekat mungkin dengan tempat tinggal petani dan mereka ditugasi merawat seribu pohon per tahun dengan cara menanam tambahan sampai jumlah itu tercapai. Pemagaran di sekeliling tanaman diperlukan untuk mencegah perusakan oleh hewan ternak. Ketentuan membersihkan tanah di sela-sela pohon dengan garu empat kali setahun bertujuan mencegah tumbuhnya belukar tanaman liar dan menanam pohon dadap sebagai tanaman antara yang berfungsi menaungi tanaman kopi muda pada pertumbuhannya. Dengan semua peraturan ini jelas menjadikan menghilangnya kopi sebagai tanaman pekarangan. Pengeringan biji kopi tetap dilakukan di rumah petani. Bupati dan kepala bawahan diwajibkan melakukan 
pembayaran langsung setelah penyetoran biji kopi muda dan pada kesibukan musim panen sedapat mungkin tidak membebani bawahannya dengan tugas lain. Terakhir, pengawas Eropa dari waktu ke waktu harus melihat tanaman dan untuk itu dia mendapat kuda dan tenaga dari bupati. Rolff memerintahkan pembuatan instruksi versi bahasa Jawa dan diumumkan di ibu kota semua kabupaten. Semua peraturan yang dibuat ini, tentu saja, terkait dengan kepentingan pemungutan upeti dan usaha yang menyeluruh dan matang untuk produk tanam pakasa (Breman, 2014: 81-82). Keterikatan petani pada lahan, pelibatan penduduk pada budi daya tanaman ekspor, larangan pindah tempat tinggal atau pindah mengabdi ke majikan lain, penetapan berbagai kepala dalam jenjang birokratis, semuanya dalam rangka satu tujuan, peningkatan upeti.

Penolakan membayar kopi dengan harga layak menyebabkan petani tergoda untuk sama sekali tidak menyetorkan hasil panen atau hanya sebagiannya saja yang menjadi kewajiban mereka. Mereka lakukan dengan membuang hasil panen itu atau menguburnya untuk menjaga agar jangan sampai dibawa ke gudang. Mereka menghindari kewajiban mereka. Ada pula yang menyerahkan kepada tengkulak yang memberi harga lebih tinggi dibanding VOC. Pengelakan monopoli ini menentang pertama-tama terhadap para kepala pribumi. Kepada para kepala inilah petani menyembunyikan transaksi ilegal yang mereka lakukan. Lebih dari yang dilakukan petani, sebetulnya para kepala lah yang menghalangi kopi yang terkumpul masuk ke gudang VOC. Dalam perjalanan ke gudang, isi pikulan berpindah tangan, sering sampai beberapa kali dan semakin mendekati gudang semakin naiklah harga yang berani dibayar tengkulak. Untuk mencegah penyelewengan ini, VOC memutuskan untuk melarang orang yang bukan penduduk tinggal di Priangan. Tindakan peraturan ini adalah penutup yang logis terhadap tanam paksa dan setoran wajib. Larangan bagi orang asing tinggal di daerah itu terutama berlaku bagi pedagang Cina yang seperti di tempat-tempat lain, bertindak sebagai perantara antara VOC dan penduduk. Mereka membeli kopi kulakan dengan uang dan atas resiko sendiri, tetapi juga bertindak sebagai agen bagi tuan tanah Eropa di sekitar Batavia atau mendapat pesanan dari pegawai VOC (Breman, 2014: 87-88). Demikianlah, penguasaan sistem ekonomi dan ekploitasi sumber daya yang dilakukan VOC di Cirebon-Priangan sampai pada akhir abad ke-18 berakhir dengan sistem ekonomi-politik khas VOC. Di

Tamaddun: Jurnal Sejarah dan Kebudayaan Islam, Volume (8), Issue (2), Desember 2020 
bawah pengaruh sistem itu, penduduk menjadi terputus kebebasannya dalam mencari sumber kehidupannya. VOC sebagai penguasa mengambil hak kepemilikan tanah dan mengklaim hak atasnya, dengan menuntut tenaga petani melalui para Bupati sebagai perantara (Hoadley 1994: 148-151, 184-5)

\section{Daftar Pustaka}

Breman, Jan, 2014, Keuntungan Kolonial dari Kerja Paksa; Sistem Priangan dari Tanam Paksa Kopi di Jawa 1720-1870, Jakarta: YOI.

Burger, D.H., 1962, Sejarah Ekonomis Sosiologis Indonesia, Jakarta: Pradnja Paramita.

Furnivall, J.S, 2009. Hindia Belanda, Studi tentang Ekonomi Majemuk, Jakarta:Freedom Institute.

Haan, F. de, 1912, Priangan, de Preanger Regentschappen Onder het Nederlandsch Bestuur tot 1811, vol I-IV, Batavia: Kolff.

Hoadley, Mason C., 1994, Towards A Feudal Mode of Production; West Java 1680-1800, Singapore: Institute of Southeast Asian Studies.

Kartodirjo, Sartono, 1988, Pengantar Sejarah Indonesia Baru: 1500-1900 (dari Emporium sampai Imperium), Jakarta: Gramedia.

Molsbergen, E.C. Godee, 1931,"Uit Cheribon Geschiedenis" dalam Gedenkboek der Gemeente Cheribon 1906-1931, Cheribon: De Staadgemeente Cheribon.

Niel, Robert van, 2003, Sistem Tanam Paksa di Jawa, Jakarta: LP3ES.

Onghokam, 1991, Rakyat dan Negara, Jakarta: Sinar Harapan.

Poesponegoro, Marwati Joened dan Nugroho Notosusanto, 1990, Sejarah Nasional Indonesia IV, edisi ke-6, Jakarta: Balai Pustaka.

Raffles, Thomas S., 1982, History of Java, Kuala Lumpur: Oxford University Press.

Sa'ban, R., 1988, Pajak Bumi di Indonesia dari Masa ke Masa: Sejarah Lahir dan Perkembangannya, Jakarta: Yayasan Bina Artha.

Vlekke, Bernard, H.M., 1959, Nusantara, A History of Indonesia, Brussel:

Uitgeversmaatschappij A. Manteau N.V. 